\title{
Customer Centricity: The Road to Financial Inclusion The Case of the Commercial International Bank (CIB) in Egypt
}

\author{
Hanan Elmoursy \\ Master of Finance \\ The American University in Cairo \\ School of Business - Department of Management \\ Nazly Hussein \\ Master of Business Administration \\ The American University in Cairo \\ School of Business - Department of Management \\ Sherif Ahmed \\ Master of Business Administration \\ The American University in Cairo \\ School of Business - Department of Management
}

\begin{abstract}
ACKNOWLEDGEMENTS
- Dr. Medhat Hassanein, Distinguished University Professor, Professor of Finance and Banking, AUC

- Mr. Amin Hisham Ezz Al-Arab, Chairman and Managing Director, CIB

- Mr. Hussein Abaza, Chief Executive Officer and Board Member, CIB

- Mr. Mohamed Sultan, Chief Operating Officer, CIB

- Mr. Mohamed Farag, Chief Digital Officer \& Head of Global Transaction Services Group, CIB

- Dr. Islam Zekry, Chief Data Officer, CIB
\end{abstract}

\begin{abstract}
The World bank defines Financial Inclusion as a means for individuals and businesses have access to useful and affordable financial products and services that meet their needs - transactions, payments, savings, credit and insurance - delivered in a responsible and sustainable way. Access to a transaction account is a first step toward broader financial inclusion since it allows people to store money and send and receive payments. A transaction account can also serve as a gateway to other financial services, which is why ensuring that people worldwide can have access to a transaction account is the focus of the World Bank Group's Universal Financial Access 2020 initiative. Financial access facilitates day-to-day living, and helps families and businesses plan for everything from long-term goals to unexpected emergencies. As accountholders, people are more likely to use other financial services, such as credit and insurance, to start and expand businesses, invest in education or health, manage risk, and weather financial shocks, which can improve the overall quality of their lives. This case sheds the light on the Commercial International Bank; CIB, one of the top Egyptian banks, its history, its financial market endeavors specifically focusing on how the bank leveraged on an existing technology to close gaps that hurdles back financial inclusion in Egypt. The case begins with a setup explaining how utilizing ACH, automatic clearing house technology, first came into focus then moves on to give a background information about CIB, its current position in the market. Afterwards, the case goes on to explain why financial inclusion is important not only on a national level but also internationally finally focusing on how CIB adopted ACH technology and what results it helped generate. With a population of over 90 million and after an uprising that put a lot of challenges on the economic situation of the country. Egyptians look forward to intuitions and organization like CIB to help them rise up not only to a challenging present but to a promising future.
\end{abstract}




\section{INTRODUCTION}

As the sun began to set on this Spring Cairo day, the CIB executive stepped out into his office balcony in Giza, to gain a sense of tranquility after a stressful work week. He was immersed in the beauty of the River Nile, and as he spent more time breathing in the fresh air, he began to reflect on the bank's current affairs.

His mind proceeded to force him to think of new ideas to stay ahead of the banking game, and he struggled to focus on the beautiful view in front of him. At the same moment, he heard a quiet knock on his open door. He was joined by a banking colleague: a top executive in the 1995 established company, the Egyptian Banks Company (EBC). EBC is owned by CBE, MOF and a number of banks, and provides shared infrastructure for electronic payment and clearing systems, which allows it to fulfil Egyptian banking sector requirements and benefit mass clients.

A conversation struck that was purely banking oriented; the Egyptian Banks Company executive showed enthusiasm in driving the banking sector to further success, through providing banks with secure, convenient, efficient and cost effective electronic payments tools appropriate to the needs of the market. This notion by the EBC executive further charged the CIB executive with energy. It was clear that a large opportunity for growth in the Egyptian banking sector exists, and it was up for grabs to whoever is deemed most innovative. As the EBC executive said his goodbyes and headed home to arrive on time for dinner with his family, the CIB executive started shuffling ideas in his mind: what was a big issue in Egypt that needed solutions, most critically now more than ever? Financial Inclusion was all over the news globally, and the World Bank has shown involvement in the Egyptian market to work on it. Leveraging on EBC being the sole clearing agent for interbank and government payment transactions and the main provider of Automated Clearing House (EG-ACH) transactions sounded like a good idea to cater to an existing need in the Egyptian market. Could this be an opportunity for the CIB?

His mind started working on overdrive; he had the existing physical infrastructure of CIB banks in Egypt, a large ATM presence in the country, in addition to a huge digital platform that could be leveraged on. There was a lightbulb moment, where an idea flashed into his mind that had the potential to make CIB leap forward ahead of any other bank in the country. He took note of it and decided to share his thoughts CIB's management team after the weekend. He took out his mobile phone and scheduled a meeting with them for the coming week.

Throughout the weekend, the CIB executive brainstormed many ideas that could cater to the Egyptian Market. On the largest scale, the global financial sector has been shifting gear to focus on financial inclusion as evidenced by the World Bank efforts and the programs it has put in place, such as Universal Financial Access 2020. Locally, the general policy of the country has slowly geared towards reaching the unbanked sector, overseeing their operations and bringing them onboard. Additionally, the CIB, being the leader in innovative banking solutions, has been true to its mission of providing top class financial solutions, creating stakeholder value and paving the banking landscape in the country. These 3 angles all overlapped on one prominent issue: the importance of financial inclusion and the essentiality of tailoring an implementation methodology to the Egyptian culture.

As scheduled, the first meeting took place between the CIB executive, CIB's director of operations as well as CIB management, where numerous discussions arose. As a result, it was agreed that the way forward should be focused on Consumer Centricity. Consequently, the vision of this new project was established on the basis of bridging the Egyptian Financial 
Inclusion gap through local, culture-driven solutions. A proposal was prepared, encompassing the roadmap towards Consumer Centricity as well as the framework for this solution, and presented to CIB management in order to obtain the approval to proceed.

As this new project ticked all the right boxes by satisfying global, local as well as the bank's visions combined, it received the green light to proceed. The CIB executive was entrusted by CIB management to form a dedicated team from the bank's various institutional divisions; namely risk management, consumer banking, retail banking, business banking, big data, ERM and others. Their involvement in the project was a key factor for its success, and the entire team were united under CIB's mission of creating innovative solutions to serve the Egyptian banking sector and create stakeholder value.

The following will showcase how this team led the CIB to great success, by proving this project roadmap successful through the team's multi-angled input. The project team took a unique banking approach, where it leveraged on what the Egyptian customer needs, as opposed to offering standalone solutions that make sense only from the bank's point of view. By going to the customer instead of waiting for them to approach the bank, and by incorporating the local culture into their solutions, the CIB was able to bring in previously unbanked personnel, and hence diminishing the financial inclusion gap in the country.

\section{CIB Background}

Commercial International Bank (CIB) is the leading private sector bank in Egypt (93.35\% free float in the Egyptian Stock Market and 6.65\% of subsidiaries wholly owned by Fairfax Financial Holdings Ltd), which offers a broad range of financial products and services to its customers, including enterprises of all sizes, institutions, households and high-net worth individuals. The Bank strives to provide clients with superior financial solutions to meet all of their financial needs. Having the strongest brand equity rightfully places CIB as the bank of choice for over 500 of Egypt's largest corporations. Moreover, CIB shows tremendous upside potential within the bourgeoning Retail and SME Banking markets. Through its superior management, high operating standards, corporate governance best practices and premier training programs, CIB has succeeded in becoming the most profitable commercial bank operating in Egypt for more than 40 years.

Moreover, CIB has succeeded to achieve great results over the last 10 years based on major transformation and visionary perspective of its management. The CIB net profits were more than tripled since the beginning of the decade, where net profits achieved in 2010 were EGP 2.141 Billion compared to the impressive amount of EGP 7.516 Billion in 2017. The only hiccup was during the revolution of 2011, which witnessed a huge decline in all the banking sector in Egypt. The net profits of the CIB over the last ten years are displayed in the chart below. 


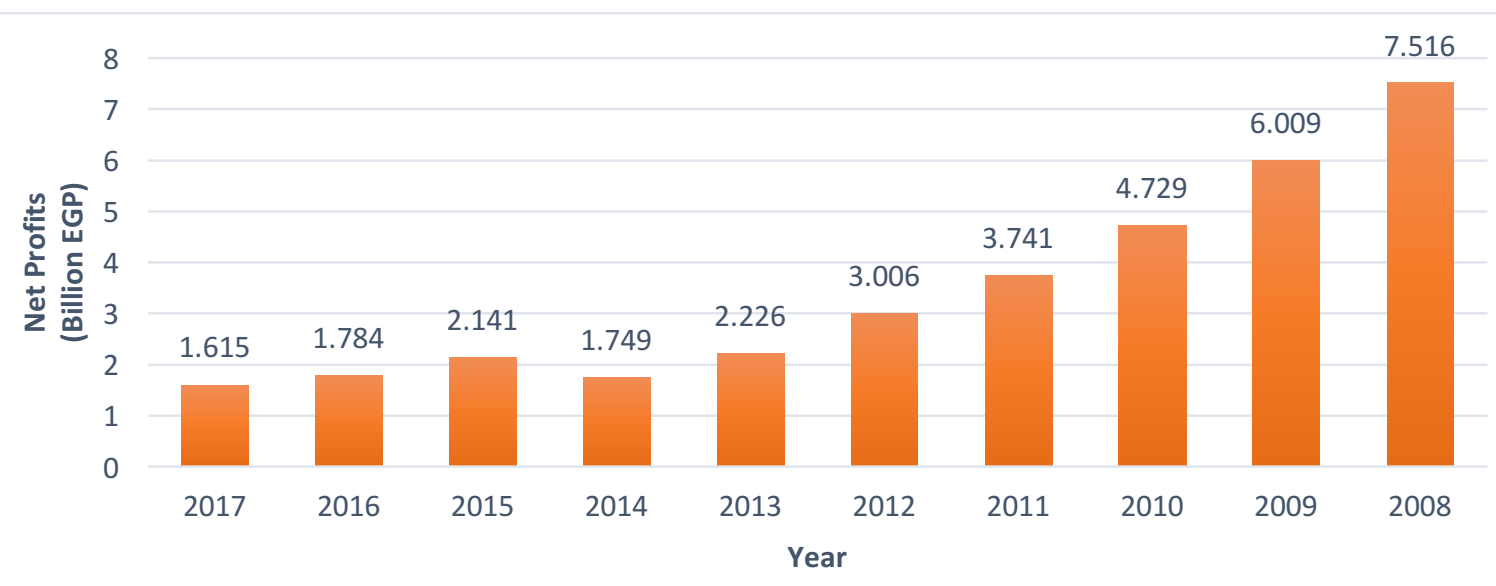

\section{CIB Vision}

"To uphold CIB's distinct reputation as a leading and trusted financial institution in Egypt, respected for its people, strong core values, performance and commitment to inclusive, responsible and sustainable growth".

\section{CIB Mission}

"To create outstanding stakeholder value by providing best in class financial solutions to individuals and enterprises that drive Egypt's economy. Through our innovative products, superior customer service, development of staff, and commitment to sustainability we will realize our ambitions and pave the landscape of banking in Egypt for years to come".

\section{CIB Objective}

"To grow and help others grow".

\section{CIB Edge}

Taking the way forward from the mission statement, CIB has managed to not only exert its maximum capacity, expertise, man power and knowledge to maximize its value, but CIB has also managed to truly reflect their mission statement and apply it to the core. The CIB uses its full potential and core competencies to provide top notch products and services that would add value to their customers. The CIB main objective is to become customer centric and to lead the banking sector to a new era of innovation and value creation to the Egyptian people and economy.

Accordingly, CIB has some outstanding competitive advantages that created an edge enabled it to attain its predetermined objectives and be ahead of its competitors. Among these competitive advantages are:

- Strong corporate business model.

- Highly experienced staff supported by continuous training to keep up with the latest industry developments and technical know-how.

- Strong customer base with a healthy and diversified portfolio that is well positioned in primary growth industries, including but not limited to: oil and gas, power, petrochemicals, infrastructure, food and agribusiness, tourism, shipping and ports and real estate.

- Ability to provide a wide and innovative array of financing schemes.

- Broad coverage including companies with sales revenues above EGP 100 million, thus establishing a foothold in this untapped segment to create future growth potential. 
- Active top management forward vision that strongly urges for innovative ideas and paves the way to effectively and efficiently implementing them.

\section{Awards}

$\checkmark$ Best Trade Finance Provider in Egypt - by Global Finance

$\checkmark$ Best Treasury \& Cash Management Providers in Egypt - by Global Finance

$\checkmark$ Best Foreign Exchange Provider in Egypt - By Global Finance

$\checkmark$ Best Bank in Egypt 2017 - by Global Finance

$\checkmark$ Best Bank in Egypt - By Euromoney

$\checkmark$ Best Bank in the Middle East 2017 - By Euromoney

$\checkmark$ Best Securities Services Providers in Egypt - by Global Finance

$\checkmark$ World's Best Bank in the Emerging Markets - by Euromoney

$\checkmark$ Best Cash Management Services in North Africa - By EMEA Finance

$\checkmark$ Best FX Services in North Africa - By EMEA Finance

$\checkmark$ Best Local Bank in Egypt - By EMEA Finance

$\checkmark$ Most Innovative Bank - Pan Africa - By EMEA Finance

$\checkmark$ Achievement in Enterprise Risk Management in the Middle East and Africa- By The Asian Banker

$\checkmark$ Achievement in Liquidity Risk Management in the Middle East and Africa- By The Asian Banker

\section{CIB Business}

In addition to becoming one of the best banks in the Egyptian market in terms of offering outstanding corporate banking to its customers, CIB also offers a wide range of other business, which include: debt capital markets, treasury and capital market services, digital banking and global transactional services, direct investment, consumer and business banking as well as investment banking services.

\section{CIB Facts and Figures as of December, 2017}

CIB has 6,551 employees who serve about a 1.1 million active customers and about 295k internet banking subscribers with more than 11.7 million website views and over 500 of Egypt's largest corporations. The CIB total asset base is EGP 294.8 billion and a deposit base that consists of $29 \%$ current accounts, $19.9 \%$ time deposits, $28.1 \%$ certificates of deposits, $21.2 \%$ saving accounts and $1.9 \%$ others.

\section{CIB Ahead of Competitors}

CIB is leading the Egyptian banking sector in terms of profitability (EGP 7.52 billion), revenues (EGP 14.88 billion), net worth (EGP 28.4 billion), market capitalization (EGP 94.8 billion) and deposit market share of $7.8 \%$ as of sep.2017

\section{CIB Shares}

CIB has 1162 million outstanding shares of EGP 10 par value representing the highest weight of $34 \%$ of the EGX 30. Moreover, the CIB outperforms the EGX 30 over the last 2 years with earnings per share of about EGP 5.76 


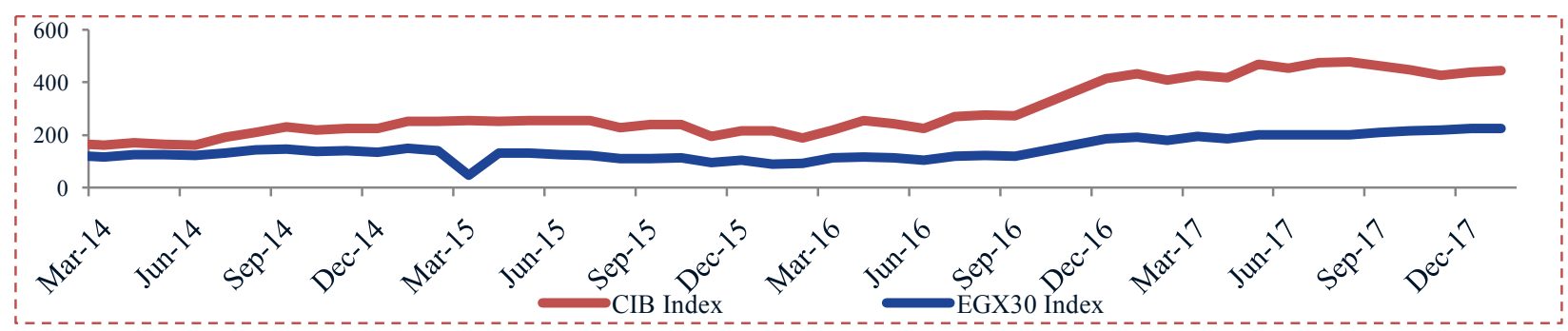

\section{Source: CIB website}

\section{CIB 2017 Achievement and Performance}

- Attracted new-to-bank accounts and grew credit facilities extended to existing clients

- Grew total loan portfolio c. $4 \%$ and total deposits 8\%.

- Participated in landmark securitization transactions

- Established new limits for existing companies

- Identified new NGO accounts to accommodate the microfinance business

- Continued to maintain moderate levels of portfolio risk and managed an effective collection of loan portfolio payments

\begin{tabular}{|c|c|}
\hline Consolidated Net Income & $\begin{array}{l}\text { - EGP } 7.52 \text { billion } \\
\text { - An increase of } 25 \% \text { y-o-y }\end{array}$ \\
\hline Standalone Net Income & $\begin{array}{l}\text { - EGP } 7.55 \text { billion } \\
\text { - An increase of } 27 \% \text { y-o-y }\end{array}$ \\
\hline Market Capitalization & - EGP 94.8 billion \\
\hline Loan Portfolio & $\begin{array}{l}\text { - EGP } 102.4 \text { billion } \\
\text { - An Increase of } 4 \% y-0-y\end{array}$ \\
\hline Deposit Base & $\begin{array}{l}\text { - EGP } 250.8 \text { billion } \\
\text { - An Increase of } 8 \% \mathrm{y}-\mathrm{o}-\mathrm{y}\end{array}$ \\
\hline ATMs & $\begin{array}{l}\text { - } 71 \text { machines added in } 2016 \\
\text { - Total } 819 \text { ATMs, of which } 96 \text { visually impaired tailored }\end{array}$ \\
\hline $\begin{array}{l}\text { Number of Transactions via } \\
\text { Cash Management Online }\end{array}$ & - $166 \%$ y-o-y Increase \\
\hline ROAE & • $32.5 \%$ \\
\hline
\end{tabular}

\section{CIB Key Business Updates}

The CIB has also achieved some outstanding performance indicators in its three main business banking as follows:

\section{Institutional Banking:}

- End-of-period gross loans were EGP 82.1 billion, almost flat QoQ and YoY.

- End-of-period deposits were EGP 51.5 billion, 13\% higher QoQ and 10\% lower YoY.

- Gross outstanding contingent business reached EGP 74 billion, 2\% higher QoQ and 4\% higher YoY.

\section{Business Banking}

- End-of-period gross loans were EGP 1.5 billion, 33\% lower QoQ and 28\% lower YoY.

- End-of-period deposits were EGP 58.6 billion, 4\% lower QoQ and 10\% higher YoY.

- Gross outstanding contingent business reached EGP 1.9 billion, 5\% lower QoQ and 8\% higher YoY. 


\section{Consumer Banking}

- End-of-period gross loans were EGP 18.8 billion, flat QoQ and 33\% higher YoY.

- End-of-period deposits were EGP 140.7 billion, flat QoQ and 20\% higher YoY.

- $\mathrm{CIB}$ continued to expand its network to reach a total of 174 branches and 22 units across Egypt, supported by a network of 819 ATMs

\section{CIB Financial Results as of End of 2017:}

\begin{tabular}{|c|c|}
\hline Revenues & $\begin{array}{l}\text { - EGP } 14.88 \text { billion } \\
\text { - An increase of } 32 \% y-0-y\end{array}$ \\
\hline ROAE & - $32.5 \%$ \\
\hline ROAA & - $\quad 2.69 \%$ \\
\hline Efficiency Ratio & - $20.8 \%$ \\
\hline Net Interest Margin & - $4.97 \%$ \\
\hline $\begin{array}{l}\text { Total Tier Capital } \\
\text { Recorded }\end{array}$ & $\begin{array}{l}\text { - EGP } 32.54 \text { billion } \\
\text { - } 19.3 \% \text { of risk-weighted assets }\end{array}$ \\
\hline Liquidity Ratio & $\begin{array}{l}\text { - Local Currency }=74.4 \% \\
\text { - Foreign Currency }=55.5 \%\end{array}$ \\
\hline
\end{tabular}

\section{CIB Digital Banking \& Global Transactions Services (GTS):}

The CIB offers a wide range of digital products and services, such as:
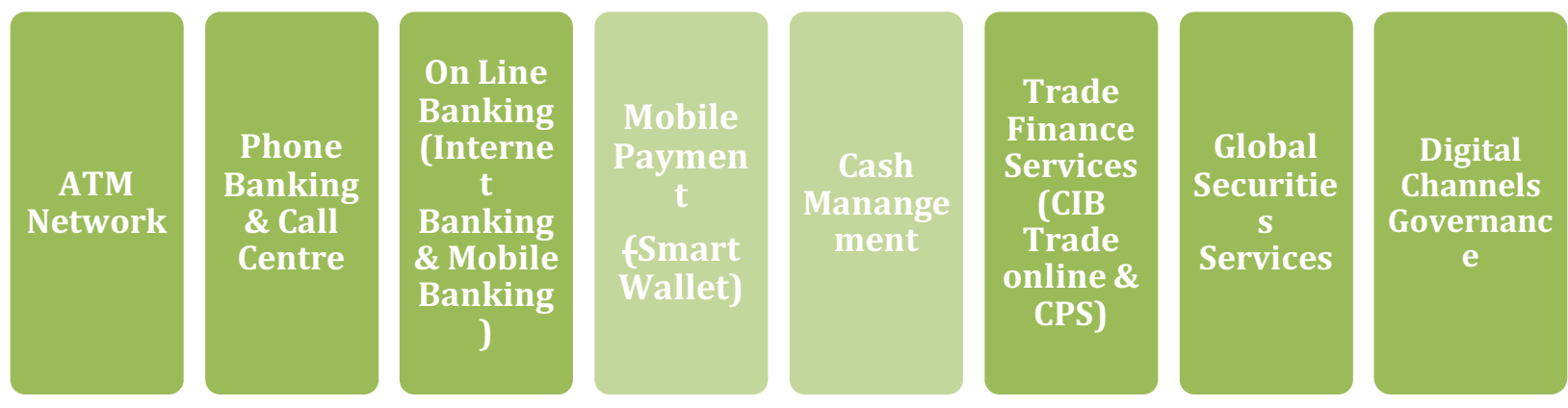

Among this wide spectrum of digital banking products and services are the CIB smart wallet and the CIB Cash Management (EG- ACH Direct). These two products are the apple of the CIB and led to a huge share of the bank's achievements and outstanding performance. Hence, it is crucial to further elaborate on them and show their evolution, accomplishments and success drivers 


\section{CIB Smart Wallet}

CIB Smart Wallet is one of the newer offerings under CIB Digital Banking. Launched in January 2016 CIB, this innovative payment experience is one of the means to achieve the desired financial inclusion. It gives both the banked and unbanked community a convenient, secure and cost effective way to make purchases through mobile devices. With just a few taps, customers can pay bills, recharge their mobile credit, send money to any other CIB Smart Wallet holder or any wallet holder in other banks, cash-in/ cash-out from CIB's ATM network and deposit/withdraw money from their CIB Smart Wallet from any Fawry retailer.

\section{Achievements}

- Increased Smart Wallet cash in balance in addition to increasing the daily and monthly transaction limits.

- Continued to rank number one in terms of activity in the local market.

- Achieved a 184\% increase as of December 2017 in Smart Wallet transactions compared to 2016.

- Ran multiple marketing activities and campaigns leveraging strategic partnerships to increase financial inclusion and wallet activity rates

\section{Forward Strategy}

Throughout 2018, CIB will be working on several different fronts, tackling on boarding and improving the user experience and customer journey pain points by increasing granularity in segmentation for both the banked and unbanked segments. In addition to upgrading their user interface and technology platform, CIB will also be adopting a multi-vendor strategy to maximise value from their existing assets to ensure they do not overlook any type of customer. The distribution network will also be a main focus area, where they will further leverage their strategic partnership and grow their agent network to register new wallets and expand their reach.

\section{Cash Management}

CIB Cash Management provides standardized and tailored cash-management products and solutions that improve the management of incoming and outgoing payments, streamline reconciliation and information management and enhance working capital efficiency. The product offering includes several innovative payment and payable products, collection and receivable products and standard and tailored information reporting delivered through a variety of channels.

\section{Achievements}

- Increased transaction volume compared to 2016, with EGP 58.4 billion in transactions completed over CIB Cash Online and Automated Clearing House (ACH) direct credit portals as of December 2017.

- CIB Trade Online reached 1,204 registered customers over its trade portal.

- Our Corporate Payment Service (CPS), which enables CIB clients to complete federal payments such as taxes, customs, and social insurance online 24/7, hit 278 customers.

- CIB ranked first among all Egyptian banks in e-finance government payments online.

- CIB currently has the largest market share among Egyptian banks for both ACH Receivable and ACH Payable:

$\circ$ Outgoing payments increased from 43,000 in January 2017 to 93,000 in December 2017.

- Internal payment increased from 33,000 in January 2017 to 67,000 in December 2017. 
- Created a feature for corporate users to be able to upload and validate checks online to reduce call-back procedures.

- In addition to the reports available at the Corporate Download Portal, new inquiries were added for post-dated checks, outgoing checks, money market, and loans.

- Cash Management's total registered clients reached 7,424 as of December 2017 due to our 24/7 accessibility at convenient sites.

- CIB ranked first in terms of volume in EG-ACH Direct Credit Outgoing.

- CIB ranked first in terms of volume in Direct Debit Outgoing.

\section{Forward Strategy}

In 2018 and beyond, CIB management members plan to continue their focus on customer migration from branches to the Business Online portal to allow customers to transact more conveniently $24 / 7$ without the need to visit a branch. They want to offer customers digital solutions that provide seamless and extensive benefits to their businesses and support them in achieving their growth trajectories. CIB Business Online seeks to become a convenient, secure, and cost-effective platform for trade and supply chain finance, cash, treasury, and lending services.

\section{Financial Inclusion:}

More than half of the world's total adult population ( 2 billion) do not have an account at a formal financial institution. Financial inclusion (i.e. Inclusive Financing) refers to the efforts embarked upon to provide accessible financial services, at affordable costs, to all individuals/businesses, regardless of their net worth/size. Its goal is to pave the way and solve the issues that hinder the participation of people in the financial sector. It is no longer a sidetopic, it is now a vital element of economic development.

The UN's Department of Economic and Social Affairs defines the goals of financial inclusion as follows:

- access at a reasonable cost for all households to a full range of financial services, including savings or deposit services, payment and transfer services, credit and insurance;

- sound and safe institutions governed by clear regulation and industry performance standards;

- financial and institutional sustainability, to ensure continuity and certainty of investment; and

- competition to ensure choice and affordability for clients.

\section{The Unbanked Sector:}

Those not linked to formal financial institutions still save, borrow and manage day-to-day expenses. Currently, cash for these operations are funded via family, friends, pawn-brokers, moneylenders, or keeping it under the mattress. These options are risky, expensive, unpredictable as well as untraceable. As they are not linked to banks, they don't have savings account, credit/debit cards, insurance, and hence do not pay the relevant taxes.

As a result of these operations, a parallel unbanked economy, that is not traceable, has emerged. It includes the diversified set of economic activities, enterprises, jobs, and workers that are not regulated or protected by the state. They are neither taxed, not monitored by any form of government. Moreover, they are not included in a country's GNP or GDP. This is either because this population has no access to banks or have developed a deep mistrust of the financial system. 
Governments are always working hard to include those individuals in the formal financial system, to help in the lending/borrowing/saving process (e-payments, e-wallets, etc.), to execute taxation policies on a larger number of citizens and to report accurate GNP and GDP economy figures.

As shown by the following chart, financial inclusion is directly proportional to GDP.

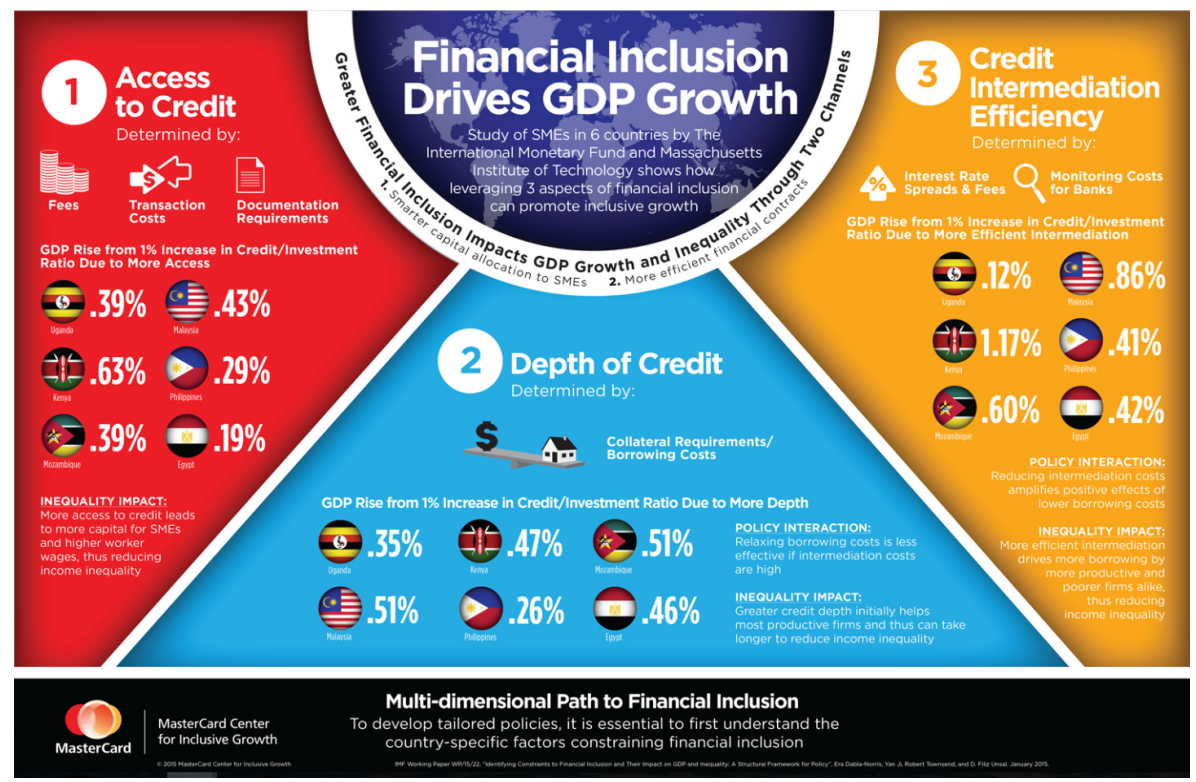

Source: MasterCard Center for Inclusive Growth (Study by the MIF and MIT)

\section{Financial Inclusion \& The World Bank: Universal Financial Access 2020}

According to the World Bank, in 2016, 2 billion people worldwide do not use official financial services, and more than $50 \%$ of adults in the poorest households remain unbanked.

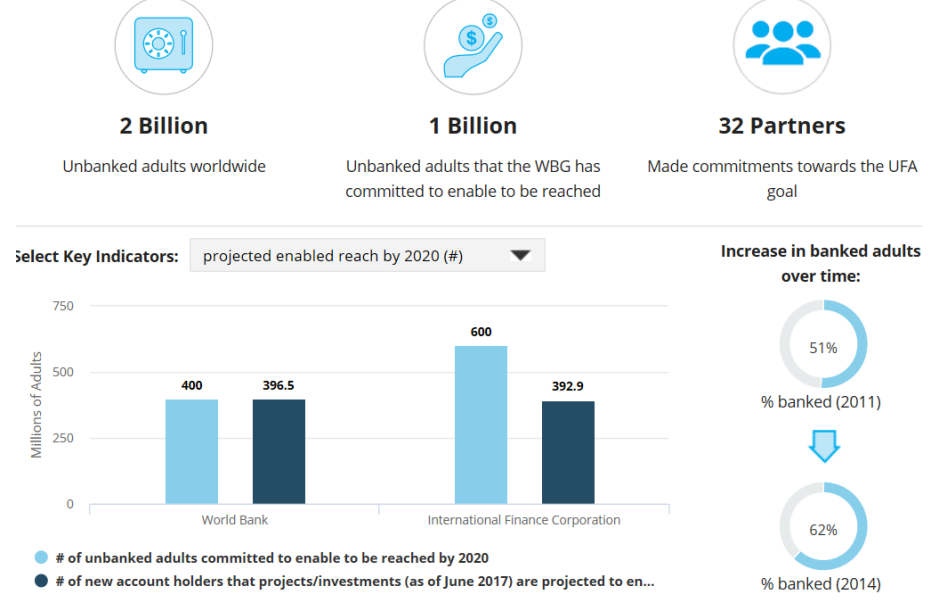

Source: World Bank

Consequently, the World Bank has embarked on an initiative to ensure that the unbanked community has access to traditional platforms by the year 2020. Hence, Universal Financial Access 2020 was born. It aims to combine the efforts of various countries under one umbrella, seeking to achieve similar goals. More than 85 countries have enhanced their efforts towards financial inclusion by developing relevant national strategies. 


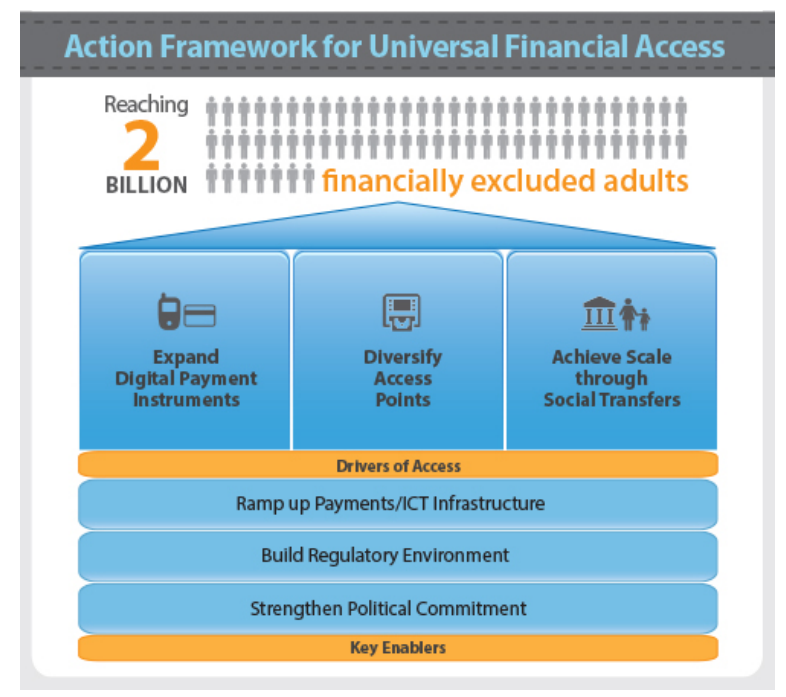

\section{Source: World Bank}

Ensuring people's access to a transaction account is the focus of the Universal Financial Access 2020 initiative. This is because having access to a transaction account is the first small step in the goal to achieving full financial inclusion, as allows people to store money, and send and receive payments, as well as serving as a gateway to other financial services.

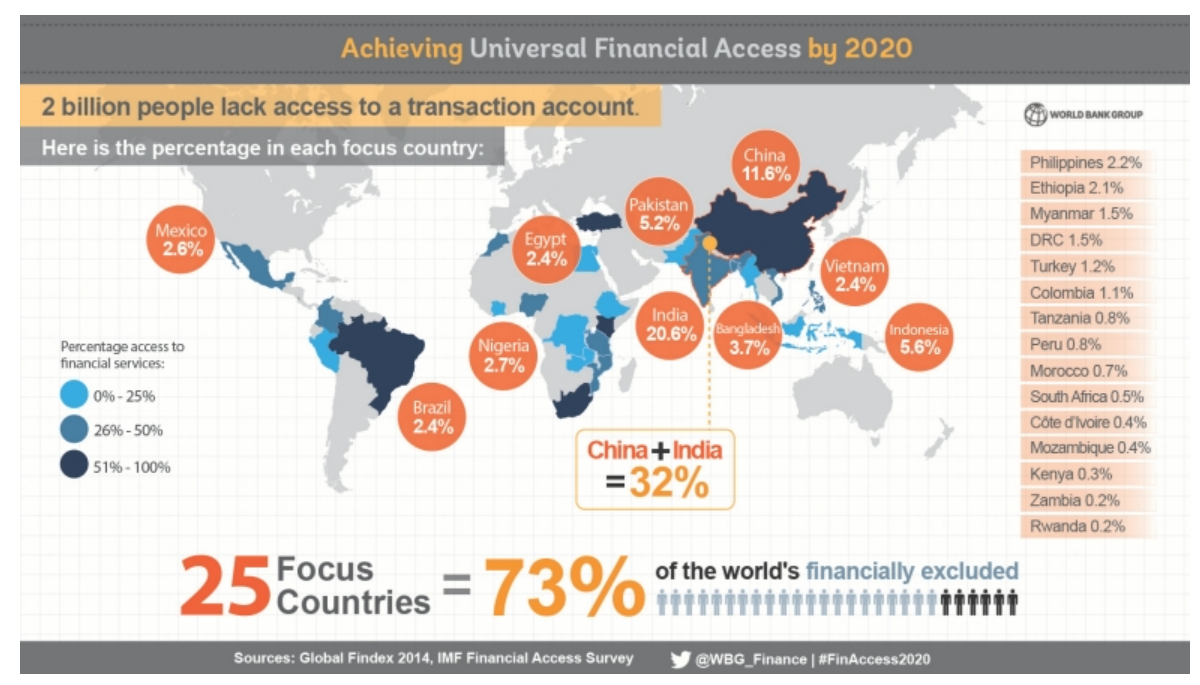

Source: World Bank

Digital financial technology has facilitated expanding access to financial services to the larger mass of populations, as well as smaller businesses, through the use of digital IDs, digitization of cash-payments, the use of mobile-based financial services serving even remote areas, as well the greater availability of customer data that allows providers to design digital financial products that better fit the needs of unbanked individuals. 


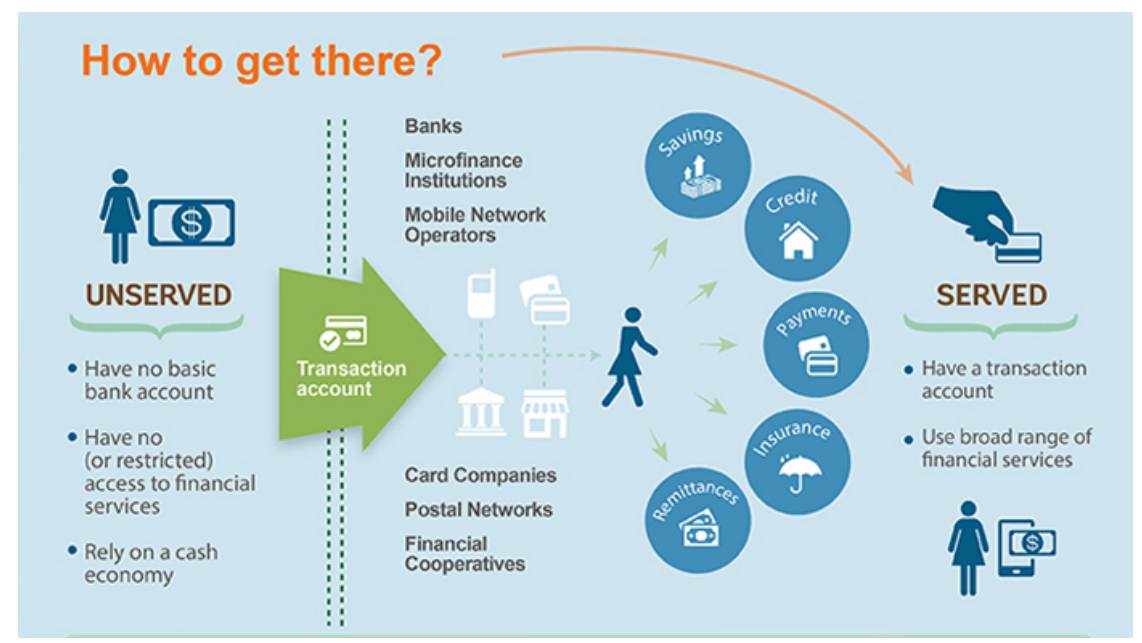

Source: World Bank

\section{Financial Inclusion in Egypt}

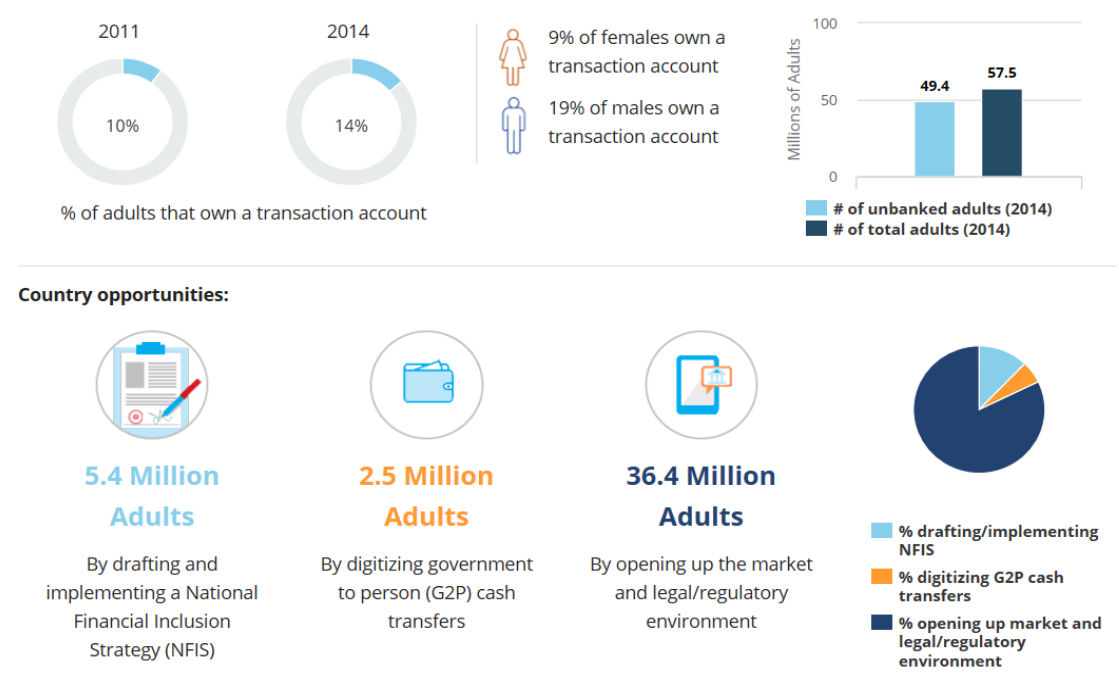

Source: World Bank

Egypt has a large financial inclusion gap hence is an opportunity with more than 44 million unbanked adults that could be brought in into the formal financial sector.

As part of the Universal Financial Inclusion initiative, which targets to bring 2 billion unbanked adults in 25 countries into formal financial systems, a three-year program was launched to focus on China, Egypt and Mexico, with a target of advancing research in digital finance and accelerating digital financial inclusion.

The three countries were chosen based on a number of factors:

- potential for country programs

- level of national government and private-sector commitment to financial inclusion

- number of people that could be reached through digital financial services

- potential for reforms to encourage innovation and digital technologies use

As shown by the chart above, Egypt has great potential for implementing initiatives to close the financial inclusion gap; this is because of the strong commitment by both government and 
private sectors to work on this front, additional to the existence of the window of opportunity due to the existing large number of unbanked sector.

As discussed earlier, financial inclusion drives GDP growth. Positive impact in Egypt can be summarized as follows:

- For every $1 \%$ increase in credit, GDP increases by $0.19 \%$

- For every $1 \%$ increase in ticket size, GDP increases by $0.46 \%$

- For every $1 \%$ increase in sales (efficiency of credit intermediate), GDP increases by $0.42 \%$

\section{CIB Initiatives to Tackle the Financial Inclusion Problem in Egypt}

CIB has recognized this opportunity ahead of its peers and has striven to think differently. The cultural perspective of Egypt will require programs that cater directly to their needs, as opposed to waiting on the customer to make the first move. Culturally, Egypt has a large population that is not aware of the banking system and how to handle it; hence CIB decided to tailor its products according to customer needs. This came naturally to CIB as it has been the market leader in innovative banking solutions, and as the CIB kept records of all customer transactions, it was able to extract buying trends from its hefty database. Furthermore, CIB decided that in order to tackle the unbanked sector, and lure it into its systems, it would need bigger infrastructure. It would need to leverage on its corporate mindset yet has to further spread its consumer banking base, rather than rely solely on corporate banking to achieve satisfactory results. Moreover, bright personnel with a similar cultural perspective needed to be brought onto the CIB team to deliver. This led to the acquiring of Citibank Egypt's retail portfolio and cards business in 2015. This was achieved due to CIB's market presence and awareness, its superior financial bid, its quick execution techniques and sound integration plans, in addition to its reputation in offering world-class service to the Egyptian customer.

Having the additional infrastructure and manpower in place, in addition to the recognition of the existing market needs led the CIB to develop the use of the Automatic Clearing House $(\mathrm{ACH})$ system, to better suit the needs of the Egyptian customer.

\section{What is ACH; why is it important?}

ACH stands for Automated Clearing House; a highly reliable and efficient network that has been adopted nationwide in the application funds transfer system governed by the Egyptian Banks Company (EBC) under the supervision of the Central Bank of Egypt (CBE).

$\mathrm{ACH}$ is an electronic fund transfer system that enables inter-bank clearing of transactions among participating financial institutions. In others words, $\mathrm{ACH}$ is a system that enables exchange of electronic transactions in batches of Direct Debit and Direct Credit payment instructions to be exchanged between participants.

The ACH infrastructure in Egypt is referred to as the Egyptian Automated Clearing House (EG$\mathrm{ACH})$. The EG-ACH could be utilized basically to transfer funds between customer's bank account, whether this transfer is a Direct Credit or Direct Debit; the low transaction cost being the main advantage of the tool.

\section{CIB Commitment to Digital Banking \& Closing the Financial Inclusion Gap}

Over the years, CIB had showed commitment to digital banking, an example of which that has been and remains the sole provider in Egypt for ATMS for the visually impaired. 
To reach a solution that would help bring on the unbanked sector in Egypt, CIB met with Top 5 consulting firms to gather ideas on how to close the financial inclusion gap. Together, they concluded that digital banking and development of ACH based on customer needs and tailoring the digital solution (platform) accordingly. There was a dilemma of the high cost to serve, hence the CIB shifted to leverage on the economies of scale concept, by utilizing the existing digital instead of solely physical platform, since capacity is not an issue in the digital world. By adding more customers to the already existing platform, cost per transaction could be brought down to remain competitive. CIB has managed to put together multi-discipline teams to avoid obstacles (transformational team), procedures were written, documented and incorporated all lessons learnt from previous cases as part of the continuous improvement process.

\section{EBC Involvement in the initiation of the EG-ACH system}

As the Egyptian Banks Company (EBC) was established in 1995 to provide shared infrastructure for electronic payment and clearing systems, it aims to fulfill the existing bank sector requirements, and to ultimately serve the end user: mass clients.

Consequently, EBC acts as the sole clearing agent for interbank and government payment transactions and hence is the main provider of Automated Clearing House (EG-ACH) transactions.

In 2010, EBC conducted a Press Conference for corporates bulk payment through EG-ACH Direct Credit.

In 2012, EBC launched the Direct Debit service, in a huge event in the presence of all banks in Egypt, with the attendance of representatives from the CBE.

Direct Debit is a quick, easy and convenient method of making regular payments such as bills, installments and subscriptions, without having to physically visit the bank. Debit is used throughout the world and is acknowledged as one of the most cost-effective and efficient methods of processing regular and periodic payments. Direct Debits are used for bill collection throughout the world, by insurance, utilities, finance, service suppliers, automobile, and other companies that receive regular and periodic payments. It is generally acknowledged by Originators to be the most cost effective and efficient method of bill collection.

\section{CIB Leveraging ACH}

The 2010 press conference conducted by EBC marked the introduction of corporates bulk payment through EG-ACH Direct Credit. CIB, being the innovative market leader in banking solutions that serve the Egyptian customer, embraced the initiative and became the first bank in the market the incorporate the ACH notion through their systems. To facilitate the CIB proposed to provide an Online Portal for Corporate and in that CIB/EBC built the First Online Portal "Corpay" for corporates. Following this initial success, EBC rolled out Corpay "ACH Online Services" to the 38 banks in Egypt across the last six years.

2013 started with the CIB dominating the ACH Direct Debit as it was the sole bank that has ACH Direct Debit service. It witnessed Shift from Bill payments/check collections/cash payments to electronic collections through building new model/cycle for installments for example: contact car; an Egyptian auto insurance and financing through building new mandates for installments. 
In 2014, CIB managed to use its well-established and successful ACH platform to replace payroll, supplier payments, pensions, executing almost $99 \%$ of local payments through ACH Credit.

Moreover, since the beginning of 2016, the CIB has managed to merge between Corporate and retail solutions through the integration between the $\mathrm{ACH}$ and Mobile Wallet platforms which proved to be a great success. CIB ACH application is the sole bank in Egypt who could credit Wallets in order to reach a huge number of non-banks customers. This exclusivity for CIB keeps the Bank advantage to create payments to over than 9 Million wallets currently exist in Egypt. Also, cash out from the Wallet could be through CIB ATMs which reached 819 machines by end of 2017 or Fawry locations, which are near to 60,000 locations in Egypt. The number of CIB Mobile Wallet subscribers are estimated to be more than 250,000 subscribers with activity rate of more than $17 \%$ as of December 2017 actually using it to carry on their transactions, such as: bill payments, mobile recharge, money transfer, online payments, donation payments, etc.

Furthermore, CIB succeeded to build an effective payment HUB through the ACH portals to auto credit, such as Outgoing Payments, Internal Payments, One-to-many Smart Wallet, CIB Prepaid Card recharge, CIB Credit Card feeding and settlement

\section{CIB Collaboration with Other Entities and Financial Institutions}

CIB Digital Banking Team started the relation with CAREEM company on September 2016 with the following proposition; providing the company with Corporate cash management online solution (Cash Online - ACH). Providing CAREEM Captains with CIB Smart Wallet to receive their dues. To do that, CIB assigned dedicated team allocated in Company branches for instant registration and conduct training for Captains. Moreover, CAREEM passengers can feed their application balance through CIB Smart Wallet, which was considered the first Model offered by a bank in Egypt to avail such service.

Moreover, as CIB is famous for innovative solutions, it decided to go to the customer instead of waiting for the customer to come to the bank. Hence, CIB realized that in order to expand its base, it had to reach Egypt's rural districts where no bank branches were present, and where the culture of the people did not encourage trade with commercial banks; white collar individuals. For this reason, and to include many unbanked personnel to the Egyptian banking system, the bank expanded to reach out through the Agriculture Bank of Egypt network. The Agriculture Bank of Egypt has more than 1200 branches nationwide, and provides mini-loans to farmers in rural areas. CIB ACH infrastructure can provide access to a large pool of people who depend mainly on the bank for getting access to financial tools. Moreover, the CIB now is working on triggering new markets, one of which is the utilization of the ACH in the brokerages companies' settlement process. This is done by continuous improvement of the system where customer feedback is generated to the system to ensure comments and misalignments are eliminated in the next application round.

\section{Adding value}

Through a strong cooperation and synergy between both of the Operations team \& Business team, CIB is currently the market leader having the largest market share among Egyptian banks for both of ACH - Direct Debit and ACH - Direct Credit over our existing ACH online Corpay portal. Moreover, ACH products and solutions have supported to increase CIB monthly payments capacity with cheaper way at the same headcount level. Accordingly, ACH Direct Credit - outgoing payments number of transactions has increased from 43K in January 2017 to 
reach 93K in Dec. 2017. Internal Payment number of transactions increased from 33K in January 2017 to reach 67K in Dec. 2017 as shown in the below two figures.
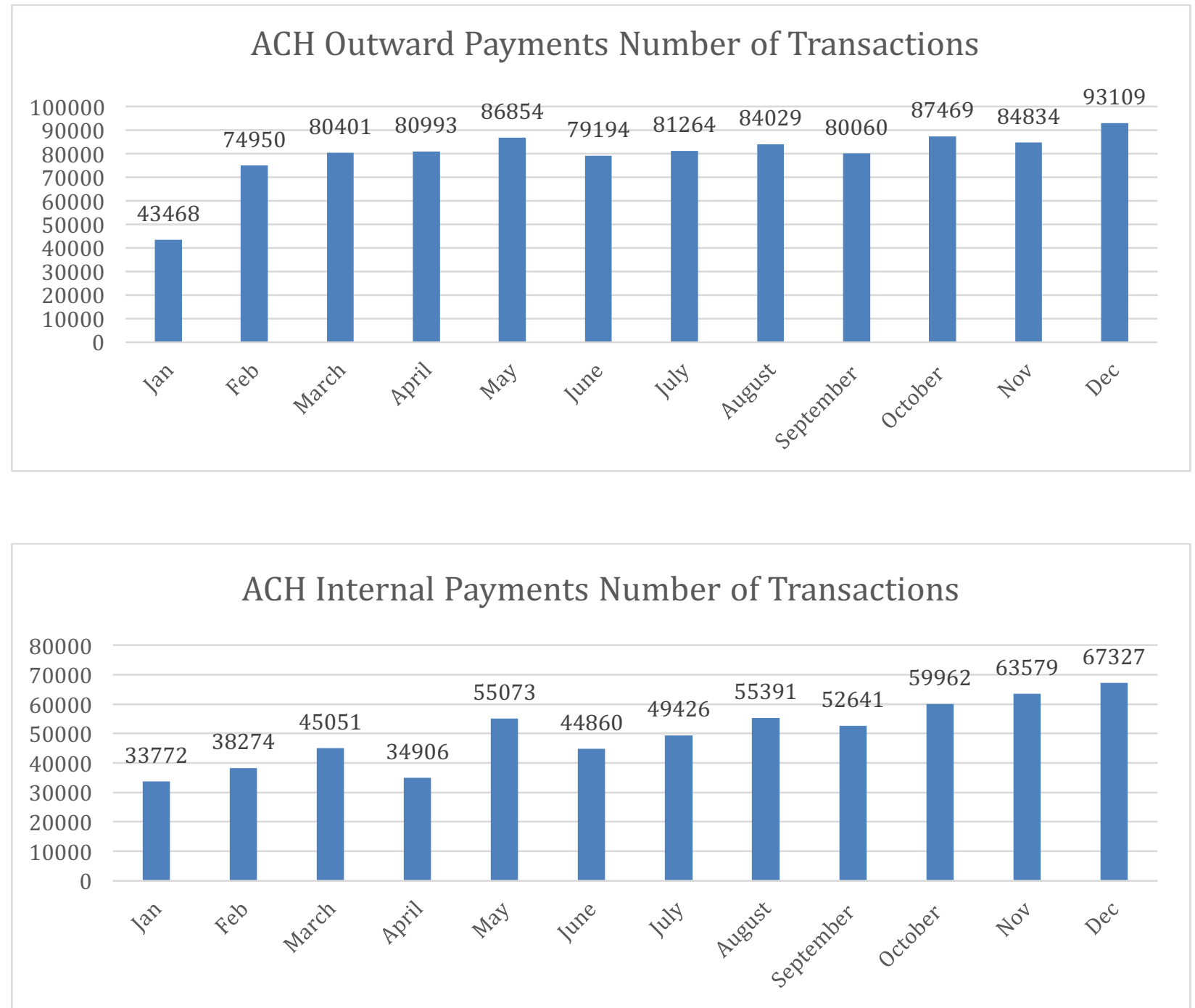

Source: CIB

Accordingly, ACH Direct Credit Internal Payments values performed inside the CIB has increased from about 725 million at the beginning of 2017 to over 779 million in December of the same year and ACH Direct Credit Outward Payments values s increased from almost 817 million to almost 2 billion up till the end of 2017 as shown in the below two figures generating 1.3 million revenues by the end of 2017. 

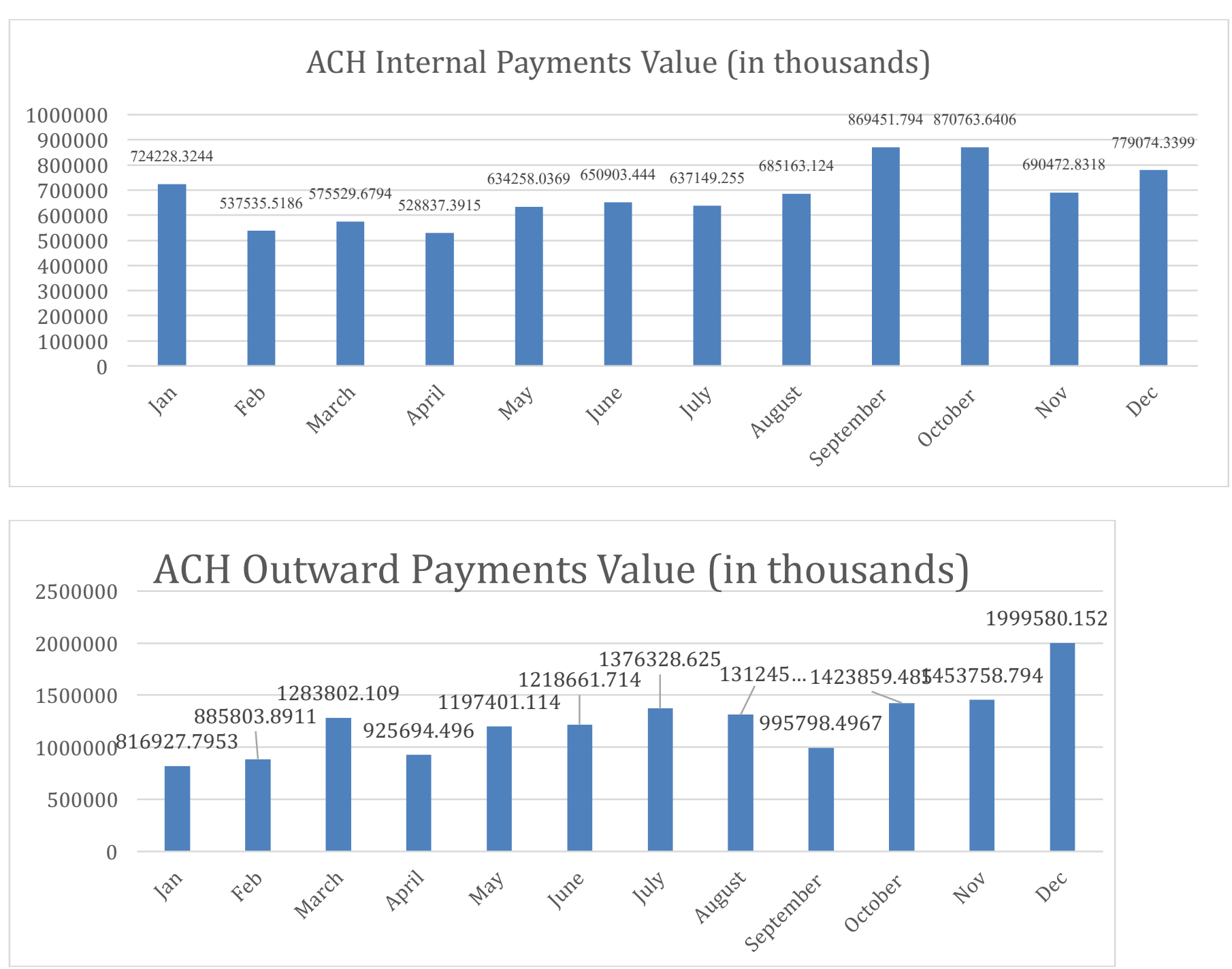

Source: CIB

Also, as evident from the below graph, Pensions and Payrolls represent over $75 \%$ of the total ACH transactions performed in 2017

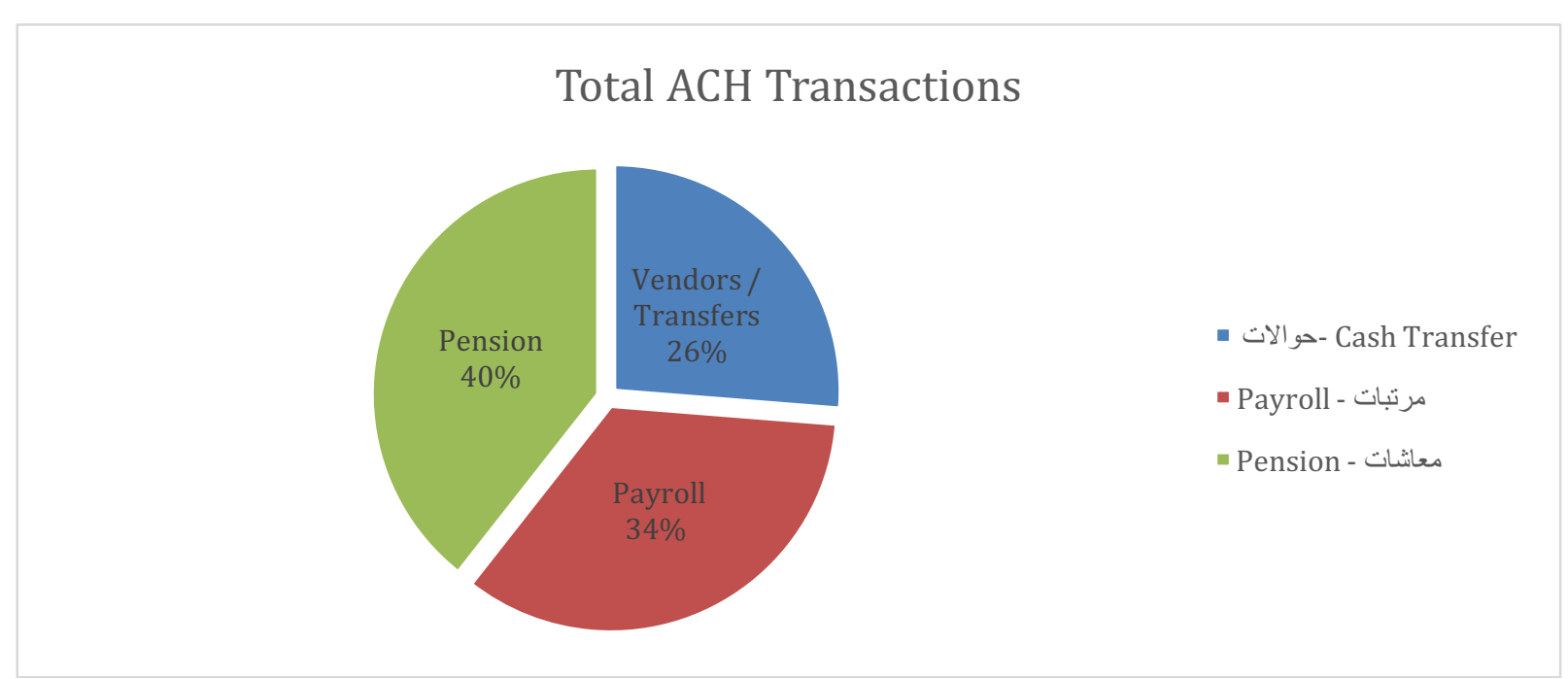

Source: CIB 
In addition, Cash Management's total registered clients reached 7,424 clients during the year 2017 due to 24/7 accessibility strategy at convenient sites. As per EBC announcement, CIB ranked first in terms of volume in EG-ACH Direct Credit. Moreover, CIB ranks first in terms of Direct Debit. Moreover, CIB launched microfinance loan instalments (presentment and collection) via CIB Smart Wallet, making CIB the first institution in Egypt to launch a service of this untapped segment. The move allowed the CIB to grow customer base and improve their reach all while catering to the needs of the microfinance market in a cost-efficient way. As well as facilitating the offsite acquisition for CIB Smart Wallet through piloting with 100 agent outlets.

ACH and other technologies that serve financial transactions are not new time but CIB pioneering as a first mover combined with highly motivated individuals and leadership that managed to leverage the technology to new heights opening new horizons of infinite possibilities that continue to add to CIB value across the years.

\section{LEARNING OUTCOMES:}

The CIB's success in reaching the Egyptian customer is unprecedented; it introduced a new implementation of an existing financial solution in Egypt that helped bridge the financial inclusion gap. CIB's initiative to tackle the financial inclusion issue by tailoring existing financial solutions to customer needs displays a new concept of putting the customer first and letting him/her set the pace. CIB sought to leverage on existing solutions, rather than reinventing the wheel, yet ensuring simplicity of implementation. This model could be adopted by other banks in the country as well as the region to further close the financial inclusion gap by growing the banked sector in Egypt.

The key success factors that can be extracted from CIB's experience can be summarized as follows:

- Operate in line with the strategy of the bank and its mission statement. CIB has followed the already-underway transformation program to further enhance its bottom-line figures. All initiatives undertaken were in line with the vision and mission of CIB, as well as its main objective of becoming customer centric and leading the banking sector in terms of innovation and value creation

- Understand the customer needs and tailor existing financial solutions accordingly to guarantee customer satisfaction, in line with the bank's objectives

- Eliminate complexity and maintain simplicity of financial solutions, keeping the customer as the key focal point

- Leverage on the existing large customer database to offer tailored banking solutions

- Utilize one's core competencies, such as the top-notch products and services that would add value to their customers

- Grow its infrastructure to be able to support future operations, such as the acquisition of Citibank Egypt retail portfolio to guarantee significant manpower in place

- Continuously look for room to grow, and find new applications for existing financial tools, in line with one's mission

- Remain innovative and ahead of competition; this will lead to the eventual paving of the way for others to follow and remaining ahead of competition

\section{References:}

About the Informal Economy | WIEGO. 2018. About the Informal Economy | WIEGO. [ONLINE] Available at: http://www.wiego.org/informal-economy/about-informal-economy.

CIB - Commercial International Bank CIB Egypt . 2018. CIB - Commercial International Bank CIB Egypt . [ONLINE] Available at: http://www.cibeg.com/English/Pages/default.aspx. 
Country Snapshot - Universal Financial Access - World Bank Group. 2018. Country Snapshot - Universal Financial Access - World Bank Group. [ONLINE] Available at: http://ufa.worldbank.org/country-progress/egypt-arab-rep.

EgyptToday. 2018. Egypt selected for World Bank financial inclusion initiative - Egypt Today. [ONLINE] Available at: https://www.egypttoday.com/Article/3/14577/Egypt-selected-for-World-Bank-financial-inclusion-initiative.

Financial inclusion - Wikipedia. 2018. Financial inclusion - Wikipedia. [ONLINE] Available at:

https://en.wikipedia.org/wiki/Financial_inclusion.

Financial Inclusion Data. 2018. Financial Inclusion Data. [ONLINE] Available at: http://datatopics.worldbank.org/financialinclusion/country/egypt,-arab-rep..

Financing for Development. 2018. Financing for Development. [ONLINE] Available at: http://www.un.org/esa/ffd/topics/inclusive-finance.html.

Ifc.org. (2018). [online] Available at: http://www.ifc.org/wps/wcm/connect/7931b811-04b3-45b5-9dc5c36a5eb5faf5/Web+version_Banking+on+Women+in+Egypt+FINAL.pdf?MOD=AJPERES

Informal sector - Wikipedia. 2018. Informal sector - Wikipedia. [ONLINE] Available at: https://en.wikipedia.org/wiki/Informal_sector.

Investopedia. 2018. Financial Inclusion. [ONLINE] Available at: https://www.investopedia.com/terms/f/financialinclusion.asp.

Press Releases. 2018. Press Releases. [ONLINE] Available at:

https://ifcextapps.ifc.org/ifcext\%5Cpressroom\%5Cifcpressroom.nsf\%5C0\%5CC6C2B26068AD032385257F4800 2E284E.

The MasterCard Center for Inclusive Growth. 2018. MasterCard Center for Inclusive Growth \& Financial Inclusion. [ONLINE] Available at: https://mastercardcenter.org/.

World Bank. 2018. Financial Inclusion. [ONLINE] Available at: http://www.worldbank.org/en/topic/financialinclusion.

World Bank. 2018. World Bank Group, ITU and CPMI launch 'Financial Inclusion Global Initiative'. [ONLINE] Available at: http://www.worldbank.org/en/news/press-release/2017/07/27/world-bank-group-itu-and-cpmilaunch-financial-inclusion-global-initiative. 


\section{TEACHING NOTES}

\section{CASE SYNOPSIS}

The World bank defines Financial Inclusion as a means for individuals and businesses have access to useful and affordable financial products and services that meet their needs transactions, payments, savings, credit and insurance - delivered in a responsible and sustainable way. Access to a transaction account is a first step toward broader financial inclusion since it allows people to store money and send and receive payments. A transaction account can also serve as a gateway to other financial services, which is why ensuring that people worldwide can have access to a transaction account is the focus of the World Bank Group's Universal Financial Access 2020 initiative. Financial access facilitates day-to-day living, and helps families and businesses plan for everything from long-term goals to unexpected emergencies. As accountholders, people are more likely to use other financial services, such as credit and insurance, to start and expand businesses, invest in education or health, manage risk, and weather financial shocks, which can improve the overall quality of their lives.

This case sheds the light on the Commercial International Bank; CIB, one of the top Egyptian banks, its history, its financial market endeavors specifically focusing on how the bank leveraged on an existing technology to close gaps that hurdles back financial inclusion in Egypt. The case begins with a setup explaining how utilizing $\mathrm{ACH}$, automatic clearing house technology, first came into focus then moves on to give a background information about CIB, its current position in the market. Afterwards, the case goes on to explain why financial inclusion is important not only on a national level but also internationally finally focusing on how CIB adopted ACH technology and what results it helped generate.

With a population of over 90 million and after an uprising that put a lot of challenges on the economic situation of the country. Egyptians look forward to intuitions and organization like CIB to help them rise up not only to a challenging present but to a promising future.

\section{TARGET AUDIENCE}

Banking and Finance Courses, Economics Courses (Money and Banking), Leadership, Banks' Board of directors

\section{KEY WORDS}

Banking Sector, Micro Finance, Financial Inclusion, Customer Centric, Automated Clearing House $(\mathrm{ACH})$, Leadership

- Effective Leadership

\section{CLEAR LEARNING OBJECTIVES}

- Operate in line with the strategy of the bank and its mission statement.

- How to become a first Mover and innovative leader in the banking sector in Egypt.

- Tailoring financial services to customers' needs

- Maintaining simplicity of financial solutions implementations

- How to bridge financial inclusion gap in Egypt

- Collaboration of different divisions and departments to achieve success

- Utilize one's core competencies

- Work in line with global initiatives and customize them according to the local needs

- Continuously look for room to grow, and find new applications for existing financial tools, in line with one's mission 
- Remain innovative and ahead of competition, this will lead to the eventual paving of the way for others to follow

\section{INTRODUCTION}

A conversation struck that was purely banking oriented; the Egyptian Banks Company executive showed enthusiasm in driving the banking sector to further success, through providing banks with secure, convenient, efficient and cost effective electronic payments tools appropriate to the needs of the market. It was clear that a large opportunity for growth in the Egyptian banking sector exists, and it was up for grabs to whoever is deemed most innovative Leveraging on EBC being the sole clearing agent for interbank and government payment transactions and the main provider of Automated Clearing House (EG-ACH) transactions sounded like a good idea to cater to an existing need in the Egyptian market. Could this be an opportunity for the CIB?

The CIB had the existing physical infrastructure in Egypt, a large ATM presence in the country, in addition to a huge digital platform that could be leveraged on. There was a lightbulb moment, where an idea flashed into the CIB executives' minds that had the potential to make CIB leap forward ahead of any other bank in the country. The CIB executive brainstormed many ideas that could cater to the Egyptian Market. On the largest scale, the global financial sector has been shifting gear to focus on financial inclusion as evidenced by the World Bank efforts and the programs it has put in place, such as Universal Financial Access 2020. Locally, the general policy of the country has slowly geared towards reaching the unbanked sector, overseeing their operations and bringing them onboard. Additionally, the CIB, being the leader in innovative banking solutions, has been true to its mission of providing top class financial solutions, creating stakeholder value and paving the banking landscape in the country. These 3 angles all overlapped on one prominent issue: the importance of financial inclusion and the essentiality of tailoring an implementation methodology to the Egyptian culture.

As a result, it was agreed that the way forward should be focused on Consumer Centricity. Consequently, the vision of this new project was established on the basis of bridging the Egyptian Financial Inclusion gap through local, culture-driven solutions. A proposal was prepared, encompassing the roadmap towards Consumer Centricity as well as the framework for this solution, and presented to CIB management in order to obtain the approval to proceed. As this new project ticked all the right boxes by satisfying global, local as well as the bank's visions combined, it received the green light to proceed. A CIB team -formed from the bank's various institutional divisions; namely risk management, consumer banking, retail banking, business banking, big data, ERM and others- was entrusted by CIB management to be united under CIB's mission of creating innovative solutions to serve the Egyptian banking sector and create stakeholder value.

\section{Case Plan and Analysis}

\section{DETAILED TEACHING PLAN AND ANALYSIS}

Banking sector in Egypt

CIB background

CIB financial performance over the last decade

Effect of CIB management forward vision on bottom line results

What is financial inclusion?

World bank global efforts to increase awareness

CIB initiatives to close the gap

CIB mission to pave the way for financial inclusion in Egypt 
What is ACH?

CIB leading the way to implement $\mathrm{ACH}$

\section{CASE QUESTIONS}

\section{How did CIB manage to put its mission and vision statements into ACTION?}

Taking the way forward from the mission statement, CIB has managed to not only exert its maximum capacity, expertise, man power and knowledge to maximize its value, but CIB has also managed to truly reflect their mission statement and apply it to the core. The CIB uses its full potential and core competencies to provide top notch products and services that would add value to their customers. The CIB main objective is to become customer centric and to lead the banking sector to a new era of innovation and value creation to the Egyptian people and economy.

\section{What are the CIB's main competitive advantages?}

CIB has some outstanding competitive advantages that created an edge, which enabled it to attain its predetermined objectives and be ahead of its competitors. Among these competitive advantages are:

- Strong corporate business model.

- Highly experienced staff supported by continuous training to keep up with the latest industry developments and technical know-how.

- Strong customer base with a healthy and diversified portfolio that is well positioned in primary growth industries, including but not limited to: oil and gas, power, petrochemicals, infrastructure, food and agribusiness, tourism, shipping and ports and real estate.

- Ability to provide a wide and innovative array of financing schemes.

- Broad coverage including companies with sales revenues above EGP 100 million, thus establishing a foothold in this untapped segment to create future growth potential.

- Active top management forward vision that strongly urges for innovative ideas and paves the way to effectively and efficiently implementing them.

\section{Effect of CIB forward vision on bottom line results}

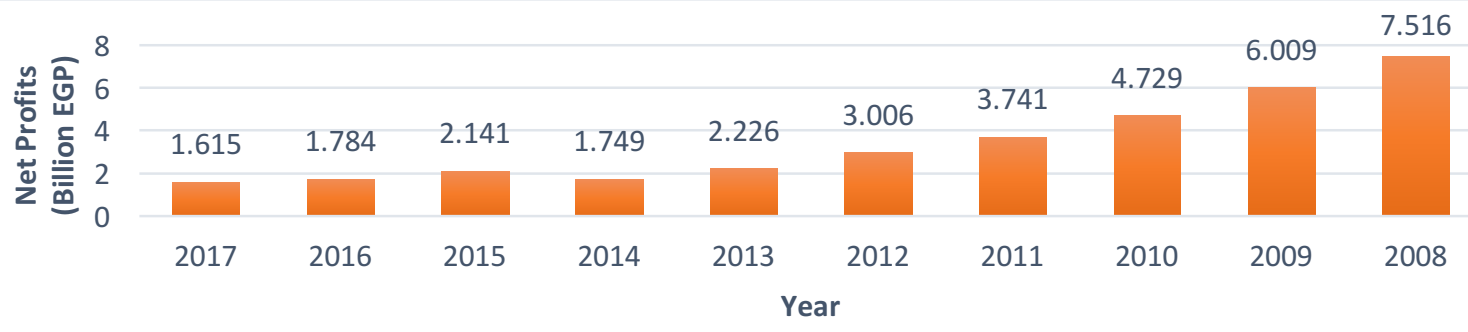

Did the CIB stock returns outperform that of the market (EGX 30)

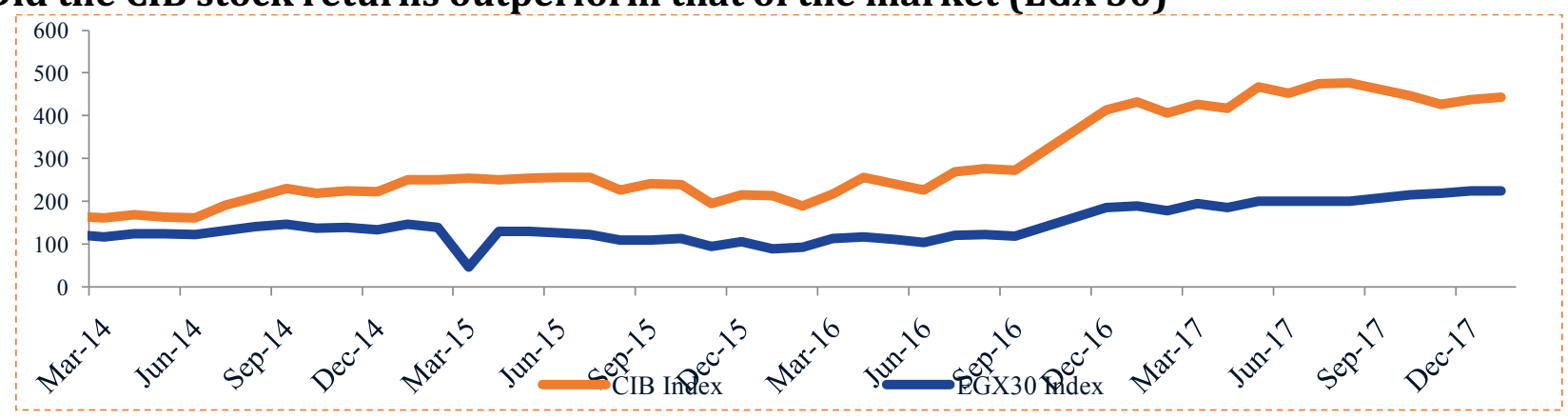




\section{What are the range of digital products and services offered by the CIB?}

\section{Digita Banking \& GTS}
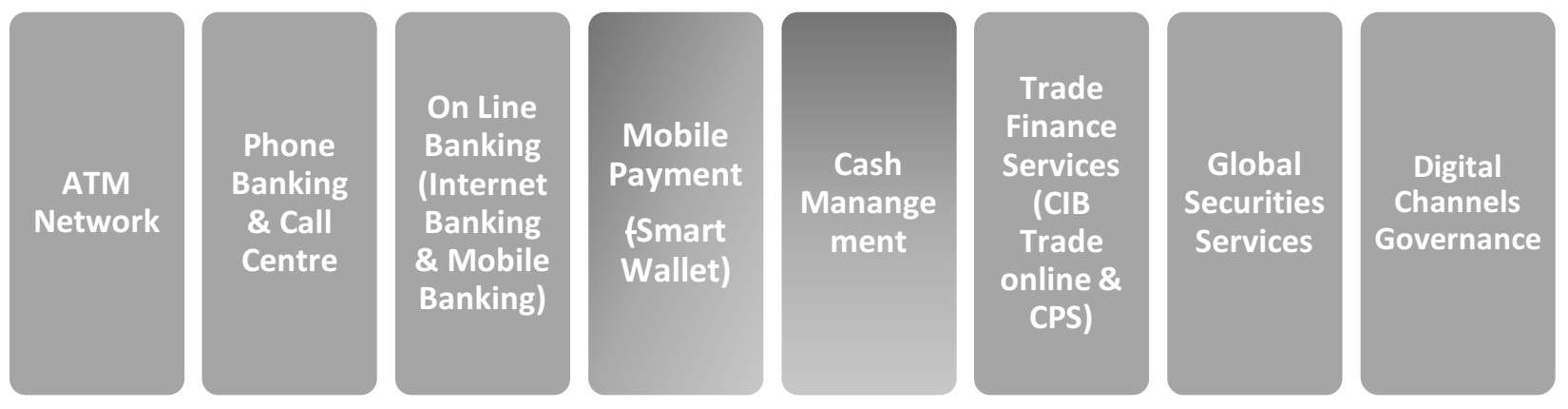

What are the three main Banking Services offered by the CIB?

- Institutional Banking

- Business Banking

- Consumer Banking

\section{Describe the CIB Smart Wallet and its Functions}

CIB Smart Wallet is one of the newer offerings under CIB Digital Banking. Launched in January $2016 \mathrm{CIB}$, this innovative payment experience is one of the means to achieve the desired financial inclusion. It gives both the banked and unbanked community a convenient, secure and cost effective way to make purchases through mobile devices. With just a few taps, customers can pay bills, recharge their mobile credit, send money to any other CIB Smart Wallet holder or any wallet holder in other banks, cash-in/ cash-out from CIB's ATM network and deposit/withdraw money from their CIB Smart Wallet from any Fawry retailer.

\section{What is the CIB Smart Wallet forward strategy?}

Throughout 2018, CIB will be working on several different fronts as follows:

- Tackling on boarding and improving the user experience and customer journey pain points by increasing granularity in segmentation for both the banked and unbanked segments.

- Upgrading their user interface and technology platform

- Adopting a multi-vendor strategy to maximise value from their existing assets to ensure they do not overlook any type of customer.

- The distribution network will also be a main focus area, where they will further leverage their strategic partnership and grow their agent network to register new wallets and expand their reach. 


\section{Describe the CIB Cash Management and its Functions}

CIB Cash Management provides standardized and tailored cash-management products and solutions that improve the management of incoming and outgoing payments, streamline reconciliation and information management and enhance working capital efficiency. The product offering includes several innovative payment and payable products, collection and receivable products and standard and tailored information reporting delivered through a variety of channels.

\section{What is the CIB Cash Management forward strategy?}

In 2018 and beyond, CIB management members plan to:

- Continue their focus on customer migration from branches to the Business Online portal to allow customers to transact more conveniently $24 / 7$ without the need to visit a branch.

- Want to offer customers digital solutions that provide seamless and extensive benefits to their businesses and support them in achieving their growth trajectories.

- CIB Business Online seeks to become a convenient, secure, and cost-effective platform for trade and supply chain finance, cash, treasury, and lending services.

\section{Define Financial Inclusion. What are the goals of financial inclusion?}

Financial inclusion refers to the efforts embarked upon to provide accessible financial services, at affordable costs, to all individuals/businesses, regardless of their net worth/size. Its goal is to pave the way and solve the issues that hinder the participation of people in the financial sector. It is no longer a side-topic, it is now a vital element of economic development.

The UN's Department of Economic and Social Affairs defines the goals of financial inclusion as follows:

- access at a reasonable cost for all households to a full range of financial services, including savings or deposit services, payment and transfer services, credit and insurance;

- sound and safe institutions governed by clear regulation and industry performance standards;

- financial and institutional sustainability, to ensure continuity and certainty of investment; and

- competition to ensure choice and affordability for clients.

\section{How did the unbanked sector emerge? What are the negative implications of this parallel, unbanked economy?}

The unbanked sector rose from the need of people to save, borrow and manage day-to-day expenses, regardless of their link to formal financial institutions. Currently, cash for these operations are funded via family, friends, pawn-brokers, moneylenders, or keeping it under the mattress.

As a result, a parallel unbanked economy that is not traceable, has emerged. It includes the diversified set of economic activities, enterprises, jobs, and workers that are not regulated or protected by the state.

These activities are not taxed or monitored by the government, hence are not reflected in a country's GNP and GDP. 


\section{Discuss the World Bank's initiative “Universal Financial Access 2020". How did it contribute to closure of the financial inclusion gap?}

According to the World Bank, in 2016, 2 billion people worldwide do not use official financial services, and more than $50 \%$ of adults in the poorest households remain unbanked.

the World Bank has embarked on an initiative to ensure that the unbanked community has access to traditional platforms by the year 2020. Hence, Universal Financial Access 2020 was born. It aims to combine the efforts of various countries under one umbrella, seeking to achieve similar goals. More than 85 countries have enhanced their efforts towards financial inclusion by developing relevant national strategies.

Ensuring people's access to a transaction account is the focus of the Universal Financial Access 2020 initiative. This is because having access to a transaction account is the first small step in the goal to achieving full financial inclusion, as allows people to store money, and send and receive payments, as well as serving as a gateway to other financial services.

Digital financial technology has facilitated expanding access to financial services to the larger mass of populations, as well as smaller businesses, through the use of digital IDs, digitization of cash-payments, the use of mobile-based financial services serving even remote areas, as well the greater availability of customer data that allows providers to design digital financial products that better fit the needs of unbanked individuals.

\section{Why was Egypt chosen as part of the World Bank's Universal Financial Inclusion Initiative? How can Financial Inclusion activities be linked to local GDP (refer to IMF/MIT chart)?}

As part of the Universal Financial Inclusion initiative, which targets to bring 2 billion unbanked adults in 25 countries into formal financial systems, a three-year program was launched to focus on China, Egypt and Mexico, with a target of advancing research in digital finance and accelerating digital financial inclusion.

Egypt was chosen based on a number of factors:

- potential for country programs

- level of national government and private-sector commitment to financial inclusion

- number of people that could be reached through digital financial services

- potential for reforms to encourage innovation and digital technologies use

Egypt has great potential for implementing initiatives to close the financial inclusion gap; this is because of the strong commitment by both government and private sectors to work on this front, additional to the existence of the window of opportunity due to the existing large number of unbanked sector.

Positive impact in Egypt can be summarized as follows:

- For every $1 \%$ increase in credit, GDP increases by $0.19 \%$

- For every $1 \%$ increase in ticket size, GDP increases by $0.46 \%$

- For every $1 \%$ increase in sales (efficiency of credit intermediate), GDP increases by $0.42 \%$

How did the CIB initiate the path towards Financial Inclusion in Egypt?

CIB has recognized this opportunity ahead of its peers and has striven to think differently: 
- CIB decided to tailor its products according to customer needs, as opposed to waiting on the customer to make the first move

- Being the market leader in innovative banking solutions, the CIB kept records of all customer transactions, and extracted relevant data accordingly

- The CIB decided to spread its corporate infrastructure, by acquiring Citibank Egypt's retail portfolio and cards business in 2015

Having the additional infrastructure and manpower in place, in addition to the recognition of the existing market needs led the CIB to develop the use of the Automatic Clearing House $(\mathrm{ACH})$ system, to better suit the needs of the Egyptian customer.

\section{How far did CIB go to solve the problem of Financial Inclusion? Was there any obstacles? and what did CIB do to run over these obstacles?}

CIB met with Top 5 consulting firms to gather ideas on how to close the financial inclusion gap. Together, they concluded that digital banking and development of ACH based on customer needs and tailoring the digital solution (platform) accordingly.

There was a dilemma of the high cost to serve, hence the CIB shifted to leverage on the economies of scale concept, by utilizing the existing digital instead of solely physical platform, since capacity is not an issue in the digital world

\section{What does ACH stand for? can you explain it in simple terms?}

ACH stands for Automated Clearing House. Just like SWIFT network, ACH is a system that enables exchange of electronic transactions in batches of Direct Debit and Direct Credit payment instructions to be exchanged between participants whether between banks, between a bank and a financial institution or between any number of financial institutions.

\section{What does Direct Debit stand for? Mention some of its uses}

Direct Debit is a quick, easy and convenient method of making regular payments such as bills, installments and subscriptions, without having to physically visit the bank. Debit is used throughout the world and is acknowledged as one of the most cost-effective and efficient methods of processing regular and periodic payments. Direct Debits are used for bill collection throughout the world, by insurance, utilities, finance, service suppliers, automobile, and other companies that receive regular and periodic payments. It is generally acknowledged by Originators to be the most cost effective and efficient method of bill collection.

\section{What does Direct Debit stand for? Mention some of its uses}

Direct Debit is a quick, easy and convenient method of making regular payments such as bills, installments and subscriptions, without having to physically visit the bank. Debit is used throughout the world and is acknowledged as one of the most cost-effective and efficient methods of processing regular and periodic payments. Direct Debits are used for bill collection throughout the world, by insurance, utilities, finance, service suppliers, automobile, and other companies that receive regular and periodic payments. It is generally acknowledged by Originators to be the most cost effective and efficient method of bill collection.

\section{Why was the year 2013 especially significant for CIB? what did CIB do after that?}

2013 started with the CIB dominating the ACH Direct Debit as it was the sole bank that has ACH Direct Debit service. It witnessed Shift from Bill payments/check collections/cash payments to electronic collections through building new model/cycle for installments for example: contact car; an Egyptian auto insurance and financing through building new mandates for installments. In 2014, CIB managed to use its well-established and successful 
ACH platform to replace payroll, supplier payments, pensions, executing almost 99\% of local payments through ACH Credit. Moreover, since the beginning of 2016, the CIB has managed to merge between Corporate and retail solutions through the integration between the ACH and Mobile Wallet platforms which proved to be a great success. CIB ACH application is the sole bank in Egypt who could credit Wallets in order to reach a huge number of non-banks customers

\section{Mention some of CIB collaborations with other Egyptian bodies that made use of ACH}

CAREEM company; CIB Digital Banking Team started the relation with CAREEM company on September 2016 with the following proposition; providing the company with Corporate cash management online solution (Cash Online - ACH). Providing CAREEM Captains with CIB Smart Wallet to receive their dues. To do that, CIB assigned dedicated team allocated in Company branches for instant registration and conduct training for Captains. Moreover, CAREEM passengers can feed their application balance through CIB Smart Wallet, which was considered the first Model offered by a bank in Egypt to avail such service

Agriculture Bank of Egypt; CIB decided to go to the customer instead of waiting for the customer to come to the bank. Hence, CIB realized that in order to expand its base, it had to reach Egypt's rural districts where no bank branches were present, and where the culture of the people did not encourage trade with commercial banks; white collar individuals. For this reason, and to include many unbanked personnel to the Egyptian banking system, the bank expanded to reach out through the Agriculture Bank of Egypt network. The Agriculture Bank of Egypt has more than 1200 branches nationwide, and provides mini-loans to farmers in rural areas

\section{Is ACH a new technology? what gave CIB an advantage over other banks? what distinguishes CIB from other banks that keep it on top of other banks in Egypt and among the top in the Middle East and Africa?}

$\mathrm{ACH}$ and other technologies that serve financial transactions are not new but CIB pioneering as a first mover combined with highly motivated individuals and leadership that managed to leverage the technology to new heights opening new horizons of infinite possibilities that continue to add to CIB value across the years.

Through leveraging on the existing technology and through a strong cooperation and synergy between both Operations team \& Business team, CIB is currently the market leader having the largest market share among Egyptian banks for both of ACH - Direct Debit and ACH - Direct Credit over our existing ACH online Corpay portal. Moreover, ACH products and solutions have supported to increase CIB monthly payments capacity with cheaper way at the same headcount level. Accordingly, ACH Direct Credit - outgoing payments number of transactions has increased from 43K in January 2017 to reach 93K in Dec. 2017. Internal Payment number of transactions increased from 33K in January 2017 to reach $67 \mathrm{~K}$ in Dec. 2017. ACH Direct Credit Internal Payments values performed inside the CIB has increased from about 725 million at the beginning of 2017 to over 779 million in December of the same year and ACH Direct Credit Outward Payments values s increased from almost 817 million to almost 2 billion up till the end of 2017 as shown in the below two figures generating 1.3 million revenues by the end of 2017.

\section{LEARNING OUTCOMES}

The CIB's success in reaching the Egyptian customer is unprecedented; it introduced a new implementation of an existing financial solution in Egypt that helped bridge the financial 
inclusion gap. CIB's initiative to tackle the financial inclusion issue by tailoring existing financial solutions to customer needs displays a new concept of putting the customer first and letting him/her set the pace. CIB sought to leverage on existing solutions, rather than reinventing the wheel, yet ensuring simplicity of implementation. This model could be adopted by other banks in the country as well as the region to further close the financial inclusion gap by growing the banked sector in Egypt.

\section{KEY SUCCESS FACTORS}

The key success factors that can be extracted from CIB's experience can be summarized as follows:

- Operate in line with the strategy of the bank and its mission statement. CIB has followed the already-underway transformation program to further enhance its bottom-line figures. All initiatives undertaken were in line with the vision and mission of CIB, as well as its main objective of becoming customer centric and leading the banking sector in terms of innovation and value creation

- Understand the customer needs and tailor existing financial solutions accordingly to guarantee customer satisfaction, in line with the bank's objectives

- Eliminate complexity and maintain simplicity of financial solutions, keeping the customer as the key focal point

- Leverage on the existing large customer database to offer tailored banking solutions

- Utilize one's core competencies, such as the top-notch products and services that would add value to their customers

- Grow its infrastructure to be able to support future operations, such as the acquisition of Citibank Egypt retail portfolio to guarantee significant manpower in place

- Continuously look for room to grow, and find new applications for existing financial tools, in line with one's mission

- Remain innovative and ahead of competition; this will lead to the eventual paving of the way for others to follow and remaining ahead of competition 